\title{
KURD-ARAB TENSIONS ALONG THE GREEN LINE: IRAQ'S ROADBLOCK TO LONG-TERM STABILITY
}

\author{
Eugene J. Palka, Ph.D. \\ United States Military Academy, West Point, New York, USA
}

\begin{abstract}
For nearly two millennia, the Kurds have inhabited a mountainous region known as Kurdistan, a territory including parts of Iraq, Syria, Turkey and Iran. Within Iraq, Kurds are the second largest ethnic group, comprising $15-20 \%$ of the population and constituting the majority of citizens in the provinces of Dohuk, Irbil and Sulaymaniyah. Historic rivalries between Iraqi Kurds and Arabs contribute to current social and political unrest, and pose an even greater challenge to long-term stability in the country. One of the most volatile issues fuelling Kurd-Arab tensions concerns the „Green Line', which on various maps separates Iraq's Kurdish and Arab populations. Initially established by Saddam Hussein in 1991, the ambiguous boundary has shifted north during Arabisation schemes and south as a result of Kurdish settlement and encroachment. More recently, on 19 March 2003, the Green Line was defined as the area controlled by the Kurdish Regional Government (KRG) and recognised by the Iraqi Transitional Government when it passed the Transitional Administrative Law (TAL) in 2004. Although the Iraqi Constitution recognises Kurdistan as a federal region, the precise boundary remains contentious. At stake are the historical ties to the territory along the Green Line, the associated oil reserves, and the status of the symbolic city of Kirkuk. Resolution of the disputed territories along the Green Line, the associated revenue sharing of the oil wealth, and the fate of Kirkuk, constitute a single, complex, multifaceted issue that will have a decisive impact on the future stability, if not integrity, of Iraq.
\end{abstract}

\section{Introduction}

The Kurds have inhabited a mountainous region commonly referred to as

Scientia Militaria, South African Journal of Military Studies, Vol 39, Nr 1, 2011, pp. 16-32. doi: $10.5787 / 39-1-100$
„Kurdistan', an areal extent that includes portions of Iraq, Syria, Turkey and Iran for nearly two thousand years (Figure 1). Despite their historical ties to the region and their 
relative homogeneity, however, the Kurds do not have a sovereign state of their own, but exist as a minority population within several states. Kurds are the second largest ethnic group in Iraq, comprising $15-20 \%$ of the population and constituting the majority of citizens in the northern provinces of Dohuk, Irbil and Sulaymaniyah. The spatial concentration of Kurds in the northern provinces has contributed to a strong sense of regionalism within Iraq and has prompted various responses from the Iraqi government in recent decades. In a broader context, historic rivalries between Kurds and Arabs have existed for centuries. In some respects, these historical tensions contribute to current social and political unrest within Iraq (as well as several adjacent countries). Meanwhile, Operation Iraqi Freedom (OIF) has been the unquestionable catalyst that has brought about unprecedented change to the political landscape in Iraq and has ushered in a new era when improved Kurd-Arab relations are essential for Iraq's long-term stability.

While some effort has been made to represent (if not pacify) and accommodate Iraq's Kurdish population, a volatile issue that continues to fuel KurdArab tensions concerns the Green Line, which on some maps, separates Iraq's Kurdish and Arab populations. Established initially by Saddam Hussein in 1991, the boundary remains nebulous because it has shifted north during Saddam's Arabisation schemes and south as a result of Kurdish settlement and encroachment, especially during the course of OIF. The Green Line was defined relatively recently, on 19 March 2003, as the area controlled by the Kurdish Regional Government (KRG) and recognised by the Iraqi Transitional Government when it passed the Transitional Administrative Law (TAL) in 2004. Although the Iraqi Constitution recognises Kurdistan as a federal region, the precise boundary continues to be a source of controversy.

Nowhere is the boundary more disputed than along the southern extent of Iraqi Kurdistan, specifically along the Green Line. Friction stems from the historical ties that families and clans have to the territory, the associated oil reserves from the Kirkuk field, and the status of the symbolic city of Kirkuk. Thus far, the collective efforts of the government of Iraq, the Kurdish government, and the United Nations have failed to produce a satisfactory compromise. While considerable progress has been made to transition from Saddam Hussein's dictatorial rule to a budding (but extremely fragile) democracy, resolution of the disputed territories, the associated sharing of oil revenues, and the fate of Kirkuk, constitute a perplexing, multifaceted issue that will have a decisive impact on the future stability, if not integrity, of Iraq.

This article begins with a brief historical background of Iraq's Kurdish population. Kurd-Arab relations are subsequently described within the context of Operation Desert Storm (1991) and Operation Iraqi Freedom (2003-2010), both of 
which were significant catalysts for change within Iraq. Current tensions are discussed in terms of the disputed territory and sovereignty, oil reserves, and the status of Kirkuk. Recognising that Kurd-Arab relations are continuing to evolve within the context of a concerted nation-building effort in Iraq, any attempt to propose a definitive roadmap to peace and stability between the two principal, ethno-linguistic segments of the country's population would be well beyond the scope of this article. Thus, I have restricted the scope of the article to describing the historical and current aspects of Kurd-Arab tensions along the Green Line in order to emphasise that, despite the media's preoccupation with other problems, this multifaceted challenge may, in fact, be the greatest impediment to Iraq's long-term stability.

\section{Historical background}

Origins

Although there is considerable debate about the origin of the Kurdish people, there is a general consensus that the Kurds have Indo-European roots, stemming from the people of Iran and Mede who migrated to present-day Kurdistan in the $7^{\text {th }}$ century AD and subsequently intermarried with the Mardi tribes. ${ }^{1}$ Limbert elaborated further that the Kurds were formed by the amalgamation of Northwest Iranians migrating from the east, who absorbed various culture traits from the indigenous people of the Zagros Mountains, while imposing a linguistic unity upon them. ${ }^{2}$ A less supported belief is that the Kurds are descendents of the mountaindwelling people of Asia Minor and are related to Georgians, Armenians and Chaldeans. ${ }^{3}$ In either case, during the time of the Islamic conquests in the region during the mid-600s, the term „Kurd' referred to a tribal nomad in the older Persian or Arab sense. ${ }^{4}$

Since the time when the first Arab armies conquered the peoples and lands of present-day Kurdistan, the Kurds have had a remarkable capacity to submit to an occupying government, yet maintaining their independence in local affairs. Located at the juncture of Arab, Persian and Turkish peoples, the Kurds have understandably adopted some of the culture traits of each, yet have long maintained a strong sense of identity, including distinct traditions, social structure, language and religion. This is not to say that there is not significant diversity among Kurds in different countries, or even within Iraq. Moreover, one should not expect that Kurdish people share unified positions on all matters. Irrespective of their internal differences and rivalries, however, Kurds have maintained their ethnic identity and longing for an autonomous homeland. 
In the aftermath of World War I

In the aftermath of World War I, the Moudros Armistice provided for the surrender of the Ottoman Empire in 1918. The Treaty of Sevres subsequently partitioned the former empire based on European Mandates and made references to an autonomous homeland for the Kurds. ${ }^{5}$ Unfortunately, the treaty was never fully implemented and was replaced in 1923 by the Treaty of Lausanne, which split the Kurdish nation among Turkey, Iraq and Iran. Nevertheless, many Kurds still use the Treaty of Sevres as the source of legitimacy for an independent Kurdish state.

Since the time of Iraq's independence in 1932, the rise of pan-Arabism in Iraq was accompanied by the continued growth of Kurdish nationalism in Kurdistan. Mullah Mustafa Barzani led a revolt against the British-installed monarchy in Iraq in 1932, emerging as the leader of the Kurdish resistance. He eventually became the organiser of the Kurdish Democratic Party (KDP) in 1946 and the party leader in 1958. In the same year, Abdul Karim Qasim overthrew the monarch and declared Iraq a republic, promising to include ethnic recognition of the Kurds within the new Iraqi Constitution. Meanwhile, Barzani consolidated his power over the next couple of years and the stage was set for increased resistance against the Iraqi government.

The Kurdish question during the Baath era

Throughout the 1960s, the Kurds pressed the Qasim government for increased recognition and autonomy, but made little headway. When the Baath party took power in 1968, however, a new dialogue was initiated. The 1970 peace agreement was signed between the Iraqi government and the Kurds of northern Iraq, forming a Kurdish semi-autonomous region. For the next several years, however, internal fighting ensued among the Kurds. In 1975, Jalal Talabani left the KDP to found the Patriotic Union of Kurdistan (PUK). Tensions subsequently increased between the KDP and the PUK, and matters became more complicated when in 1978, Abdullah Ocalan established the Kurdistan Workers' Party (PKK).

At the outset of the Iran-Iraq war in 1980, there was not even a notion of a unified Kurdistan, but as geographers have witnessed elsewhere, a common enemy can often prove to be an effective centripetal force. As such, it was not surprising when the two rival parties (KDP and PUK) joined forces in 1987 to become the Iraqi-Kurdistan Front. The KDP, however, had sided with Iran during the war, prompting a retaliatory strike from Saddam Hussein in 1988. During his infamous Al-Anfal (or spoils of war) campaign, the Iraqi army employed chemical weapons and slaughtered thousands of Kurdish soldiers and civilians. Sarin nerve gas and mustard gas were used in the attack on the town of Halabja on 16 March 1988, 
killing an estimated 5000 Kurdish civilians. ${ }^{6}$ In a campaign of genocidal proportions, Saddam sought to eradicate the Iraqi Kurds as a distinct social-political community in Iraq completely. ${ }^{7}$ Within the three Kurdish governorates, roughly $80 \%$ of the villages were destroyed and nearly 100000 lost their lives. ${ }^{8}$ Hundreds of villages were razed and more than 1,5 million Kurds were uprooted, with many forcibly displaced elsewhere in Iraq or fleeing into adjacent countries. . Additionally, the Iraqi army regained the territory that had been controlled by the KDP or PUK during the war.

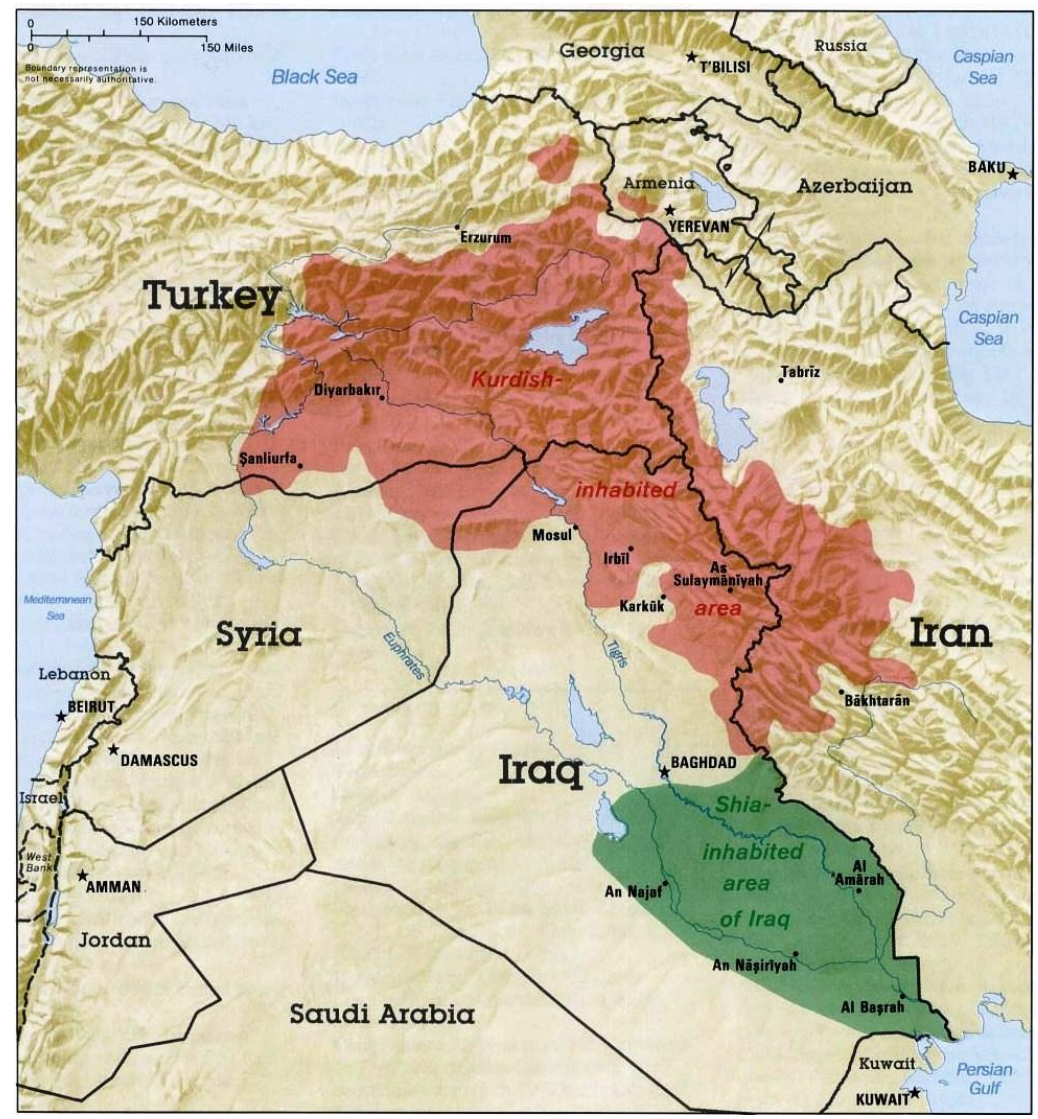

Map 1. Kurdish Lands (Kurdistan) ${ }^{10}$

The Anfal campaign might also be viewed as the bloody conclusion of Saddam's „Arabisation' of Kirkuk, an effort to extend Iraqi-Arab control over the city's oil wealth. ${ }^{11}$ Using both direct and indirect pressure, such as job 
discrimination, property confiscation, violence and threats, Iraqi-Kurds were forced out of the city and replaced with Arab residents who had been provided with incentives or who have been strongly ,encouraged' to move into the city in order to change the demographics from a Kurdish to an Arab majority. ${ }^{12}$

\section{The Gulf War}

Both the KDP and PUK officially condemned Iraq's 2 August 1990 invasion of Kuwait. However, fearing another Anfal campaign, both parties were initially reluctant to act beyond their political rhetoric. Later, in the immediate aftermath of Operation Desert Storm, a general uprising occurred among the Shia in the southern part of the country. The weakened Iraqi government, Shia rebellion, and encouragement by the US to overthrow Saddam Hussein's regime motivated Masoud Barzani to capture the town of Raniya. ${ }^{13}$ On 19 March 1991, Kurdish forces also captured Kirkuk, the high point of the rebellion. ${ }^{14}$ Although the Kurds experienced early success against a demoralised Iraqi army, Saddam's Republican Guard effectively crushed the Kurdish uprising in a matter of weeks, recapturing Kirkuk, while inflicting heavy casualties. Additionally, Saddam renewed Arabisation efforts, especially in Kirkuk. A large percentage of the Kurdish population was evicted, administratively transferred elsewhere, or pressured into selling their property to Iraqi Arab settlers. ${ }^{15}$ Thousands of Kurdish residents left Kirkuk, and with recollections of the Anfel campaign, over a million Kurds fled from northern Iraq to Iran and Turkey. ${ }^{16}$

With the collapse of the Kurdish uprising and the Kurdish issue becoming internationalised, the Coalition sought to prevent reprisals, assisted the thousands of Kurdish refugees, and enabled the continuation of humanitarian projects in northern Iraq. The UN adopted Resolution 688 on 5 April 1991, enabling the Coalition to establish a northern no-fly zone, conduct Operation Northern Watch, and prompt Saddam Hussein to withdraw his troops from the Kurdish region (Figure 2). The Iraqi army subsequently occupied positions along a defensive line, which would eventually become known as the „Green Line'.

Internal conflict in Kurdistan

Under the protective umbrella of Operation Provide Comfort, displaced persons began to return to Kurdistan and the Kurdish leadership began to press for implementation of the 1974 Autonomy Law, focusing on specific areas such as Kurdish identity, language, security, territory and democratisation. ${ }^{17}$ Kurdish regional government elections were conducted on 19 May 1992. Ironically, as 
opposed to unifying the Kurds, the election results revealed the internal rift, with 51 seats of the legislative assembly going to the KDP and 49 seats to the PUK, while in the presidential election, Barzani prevailed over Talabani with $44,6 \%$ versus $44,3 \%$ of the votes. ${ }^{18}$ Moreover, the split government became stagnant and ineffective, as it proved incapable of gaining a consensus on any key issues. ${ }^{19}$

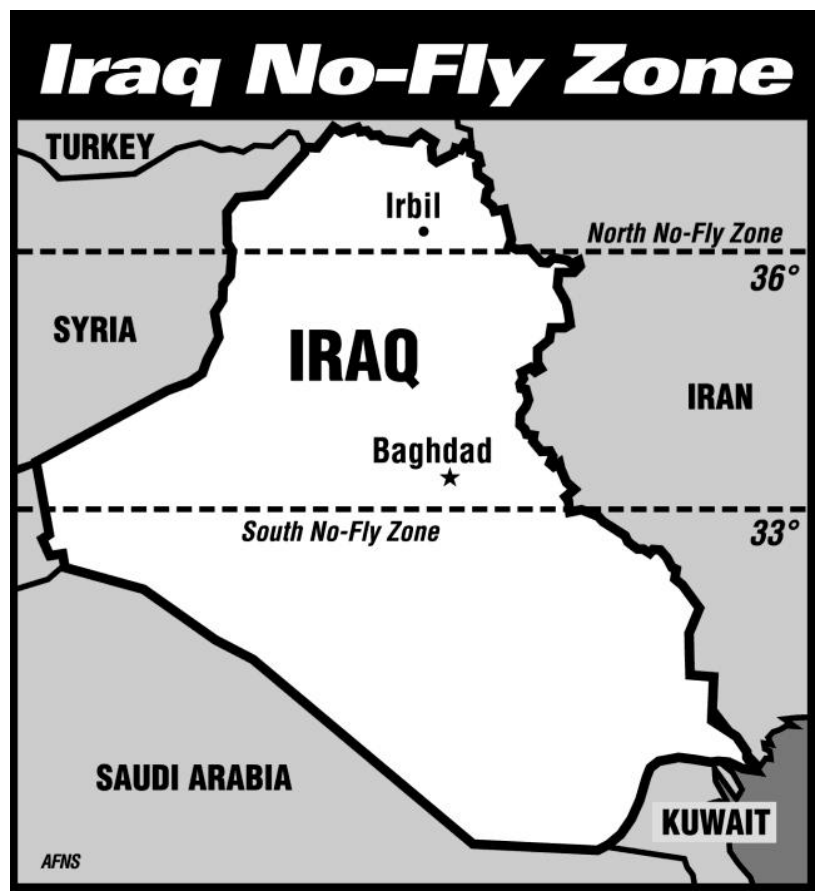

Map 2: Operation Provide Comfort and northern no-fly zone $\left(36^{\circ} \text { north }\right)^{20}$

By 1994, internal tensions had grown worse and a land dispute served as the catalyst for widespread violence and fighting between the KDP and PUK. Fierce battles ensued between the factions, and thousands of casualties resulted from attempts to seize and control Irbil. Internal fighting reached a new height in 1996 when Iran's perceived support of the PUK prompted the KDP to invite Saddam Hussein and the Iraqi army north of the Green Line. After the Iraqi army had captured Irbil on behalf of the KDP, the US pressed for and eventually hosted a meeting in Washington between Barzani and Talabani, resulting in the Washington Agreement of September 1998, whereby Barzani and Talabani committed themselves to power sharing in the region. ${ }^{21}$ Although political rivalries continued during the period leading up to Operation Iraqi Freedom (OIF) in 2003, cooperation 
between the PUK and KDP improved to the point of presenting a unified front on the eve of the war.

\section{Operation Iraqi Freedom (OIF)}

During the first three years of OIF (2003-2006), the Kurds emerged as an ally for the United States, with Kurdish peshmerga fighting alongside American troops throughout the northern third of the country. ${ }^{22}$ It was not surprising that the Kurds were receptive to American troops, given the US support for the Kurds during Operations Northern Watch and Provide Comfort in the aftermath of Operation Desert Storm. Additionally, to Kurdish leaders, the US incursion seemed to afford an opportunity to settle old scores or at least address issues that had been given little attention during Saddam's reign. The favourable relationship with the US proved advantageous as the Kurds made significant political gains, to include acquiring a greater voice in Baghdad, gaining recognition of the KRG as a federal entity, and establishing de facto control of Kirkuk. ${ }^{23}$

Shifting the Green Line

The Transitional Administrative Law (TAL) added legitimacy to Kurdish territorial claims by defining the Green Line as the boundary where the KRG had control as of 19 March 2003 (Figure 3). In 2004, the Iraqi transitional government passed TAL Article 53 (A) recognising the existing KRG and its right to continue existence within the new state of Iraq, with authority over the territories that were administered by that government on 19 March 2003 in the governorates of Dohuk, Irbil, Sulamaniya, Kirkuk, Dialya and Ninevah. Subsequently, the Iraqi Constitution (IC) chose to not modify the Green Line or establish a new boundary for Kurdistan, but to recognise the KRG as a federal region and adopt the Green Line as defined by the TAL until the disputed territories and status of Kirkuk were resolved. Additionally, Article 140 requires the government of Iraq (GOI) to conduct a referendum in Kirkuk and other disputed territories in order to determine the will of their citizens and placement within either the KRG or other provincial control.

Changing alliances

Concurrent with the progress made by the Kurds since 2006, the US has made concerted political efforts to take into account the demands of Sunni Arabs through initiatives such as Awakening Councils and the Sons of Iraq, while also attempting to make peace with Shia Arabs, resulting in the Maldi army declaring a ceasefire on 29 August $2007 .{ }^{24}$ These inroads and improved relationships with Sunni 
and Shia Arabs raise the perception of „shifting alliances' and have caused some distress among Iraqi Kurds. Some Kurdish officials are already worried about the prospects of increased violence after the planned withdrawal of US forces. ${ }^{25}$ Local residents throughout various parts of Iraqi Kurdistan also routinely express their concerns with the planned departure of US troops. ${ }^{26}$ Civilians and military personnel alike fear that the relationships forged between the Iraqi and peshmerga armies will dissolve with the withdrawal of US troops by the end of $2011 .{ }^{27}$ In the minds of some Kurds, the US is regarded as the "protector against Arab enmity and the guarantor of their security". ${ }^{28}$

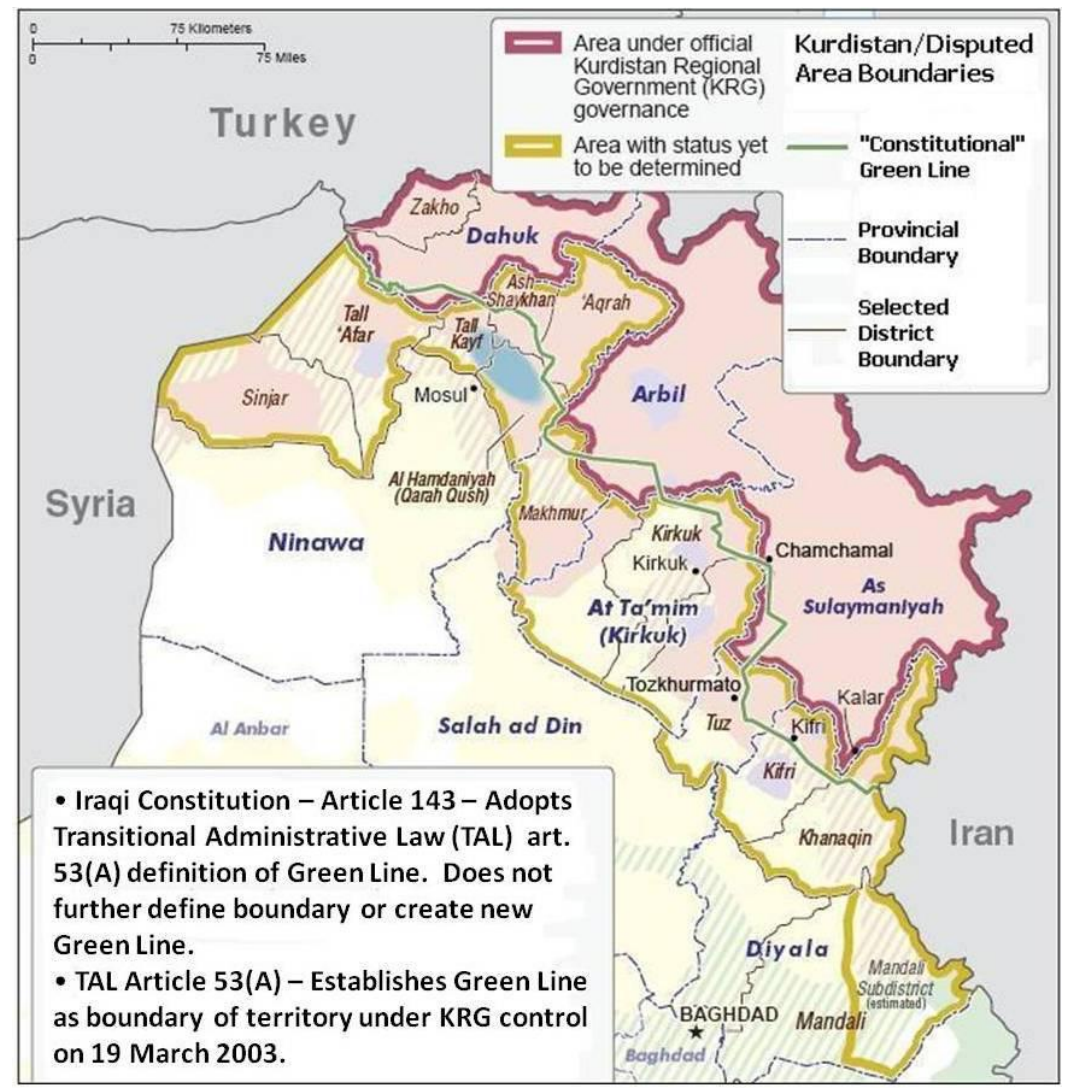

Map 3: Iraq's „Green Line,29

Despite the varying perceptions, the official US policy has been unambiguous, calling for a unified Iraq that supports autonomy (versus 
independence) for Iraqi Kurds. ${ }^{30}$ To be sure, US troops have devoted significant efforts to mediating between the pesh and Iraqi militaries. The goal has always been to promote a constant dialogue and spirit of cooperation between the two, in an effort to facilitate reconciliation and promote nation building. Thus, the US has never taken sides, nor are they currently shifting allegiance. Rather, the position has been one of mediating, with hopes that the historical tensions can be overcome with improved communications and the prospects of a shared future. ${ }^{31}$

\section{Current issues and tensions}

Unfortunately, despite the existing legislation, the boundary separating the Kurdish region from the rest of Iraq has never been defined with any degree of specificity. Until the procedures established by the IC in Article 140 are complete, official borders cannot be determined. In some respects, this scenario has historical roots and has evolved considerably since Iraq's independence in 1932. Others suggest that the current dilemma is an unexpected consequence of the US incursion in 2003. ${ }^{32}$ As Stewart notes, under Saddam Hussein's oppressive regime, the Kurdish minority and Shia majority were tightly controlled, but now in the absence of a strong central government, each group is seeking a greater amount of territory and/or power. ${ }^{33}$ Irrespective of whether the multifaceted problem is an historical one or a product of the US-led OIF, the yoke has been removed from the Iraqi Kurds, who were systematically persecuted during Saddam's reign, and now the new Iraqi government (and in some respects) the international community must contend with a situation that has been brewing for decades. Meanwhile, tensions persist over territory and sovereignty, the status of Kirkuk and the Kirkuk oil field.

Territory and sovereignty

Officially, the provinces of Dahuk, Irbil and Sulaymania fall entirely within Kurdistan and under KRG control. Kurdish claims, however, extend from Khanaquin and Mendeli in the east (along the Iranian border) to Sinjar and Tal Afar in the west (near the border with Syria). Contested areas also include parts of Diyala province, areas in and around the city of Mosul, and the symbolic city and environs of Kirkuk.

While the Kurds point to Arabisation campaigns during the Ba'ath era that included „land grabs', forced migration schemes, and encroachment upon their territory, they have made a concerted effort in recent years to recoup lost ground and to establish buffers to protect their lands. In a general sense, the Kurds have established a civilian and peshmerga presence in all of the disputed areas, in an 
effort to protect its citizens and interests, halt encroachment, and prevent attacks on the ,inner ring' of Kurdistan. ${ }^{34}$ Meanwhile, Iraqi Arabs fear the effects of reverseArabisation in contested areas and point to the unauthorised use of peshmerga outside of Kurdistan as a means for the KRG to expand both influence and territory. ${ }^{35}$ Prime Minister Maliki has resorted to employing Iraqi army units on several occasions to counter peshmerga provocations well outside of the KRG boundaries. ${ }^{36}$

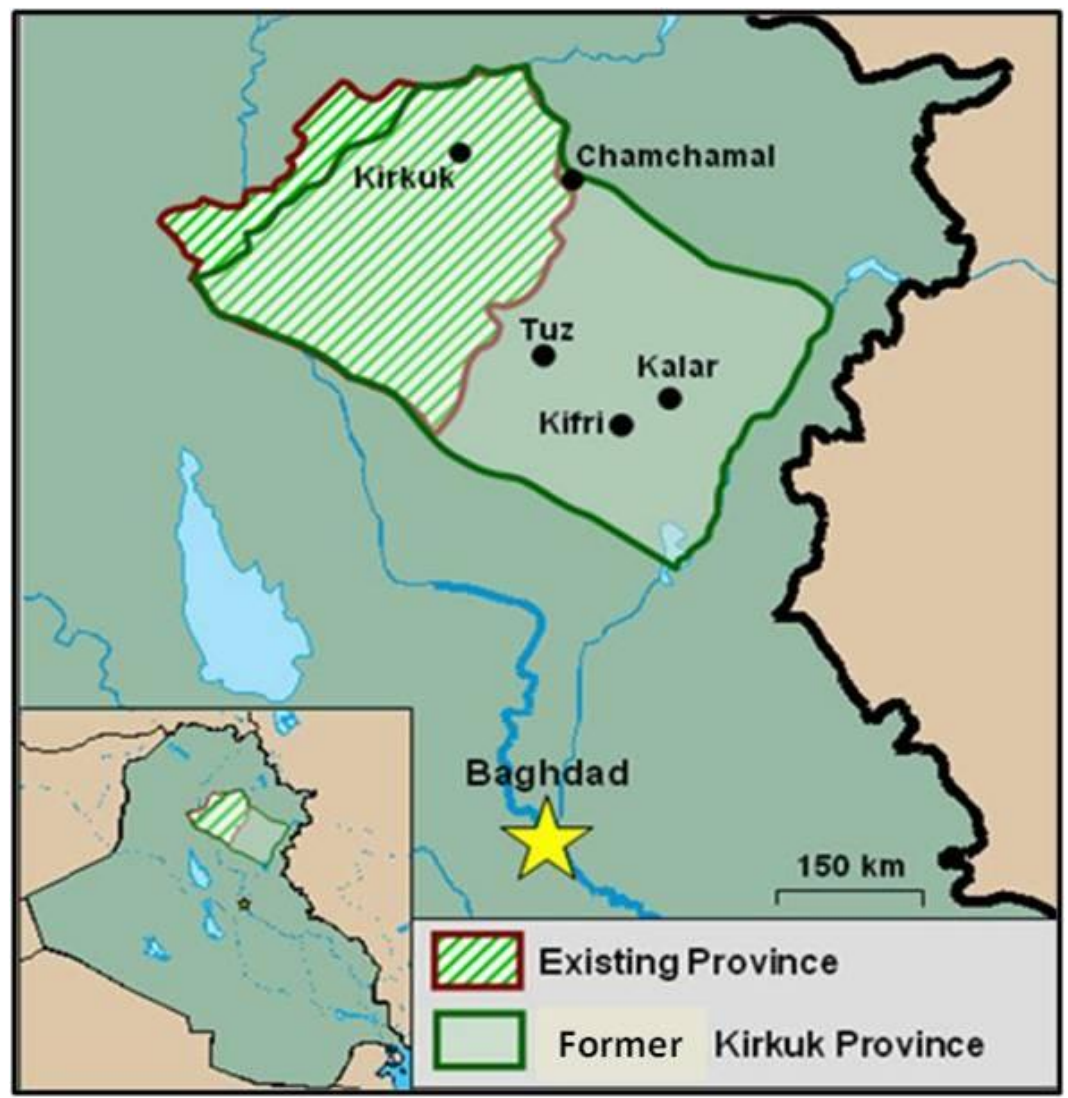

Map 4: Contested space showing current boundaries of At Tamim province in red and pre-1976 boundaries of Kirkuk province in green. ${ }^{37}$ 
Status of Kirkuk

The eventual status of Kirkuk remains one of the most divisive issues among Iraqi Arabs and Kurds, not to ignore the sentiments of the city's substantial Turcoman population. There has not been a reliable census since 1957, and demographics have since changed considerably once Iraqi Ba'thists began initiating Arabisation policies in 1968, resulting in mass deportations and ethnic cleansing from the 1970 s through the $1990 \mathrm{~s} .{ }^{38}$ Kurds are convinced that prior to Saddam's Arabisation efforts, nearly $75 \%$ of Kirkuk's population was Kurdish, with the remaining 25\% being Turcoman and Arab. ${ }^{39}$ Kurds contend that the demographics of the city and of the former Kirkuk province, changed only after Kurdish residents were evicted and Iraqi Arabs incentivised to move in (Figure 4). Conversely, Iraqi Arabs suggest that Kurdish migrants have returned in droves to the city since 2003 in an effort to shift the demographic balance prior to an official census.

The importance of Kirkuk's symbolism as the future capital of Iraqi Kurdistan probably pales in comparison to the importance of the oil riches within its hinterland. The Kirkuk oil field is a vast source of crude and revenue for Iraq, and despite proposed revenue sharing stemming from legislation, control and security of the resource is a most contentious issue. In early 2009, Prime Minister Nouri alMaliki deployed Iraqi army units (loyal to the central government) to the vicinity of Kirkuk, considerably increasing tensions with the KRG and peshmerga. The volatile situation prompted the US to increase its troop level in the area from a combat battalion task force of about 900 soldiers to a brigade combat team of more than 3200 personnel. ${ }^{40}$ While some KRG officials are reluctant to accept any arrangement that prevents the KRG from annexing Kirkuk, others suggest an arrangement whereby the city can be managed jointly by the central government in Baghdad and the KRG. ${ }^{41}$

Oil

Iraq has the world's second largest endowment of oil, with an estimated 115 billion barrels of proven crude oil reserves, accounting for more than $11 \%$ of the global output (Figure 5). ${ }^{42}$ Since 2005, Article 108 of the Iraqi Constitution has established the principle that Iraq's oil and gas are the ownership of all the people of Iraq in all the regions and governorates and that revenue must be distributed evenly per capita, with Article 109 enabling some weighting for disadvantaged provinces. ${ }^{43}$ The draft Federal Hydrocarbon Law, approved by the Iraqi cabinet on 27 February 2007, further stipulates that the Federal Oil and Gas Council has 
responsibility for managing the associated policies, exploration, laws and pipeline developments.

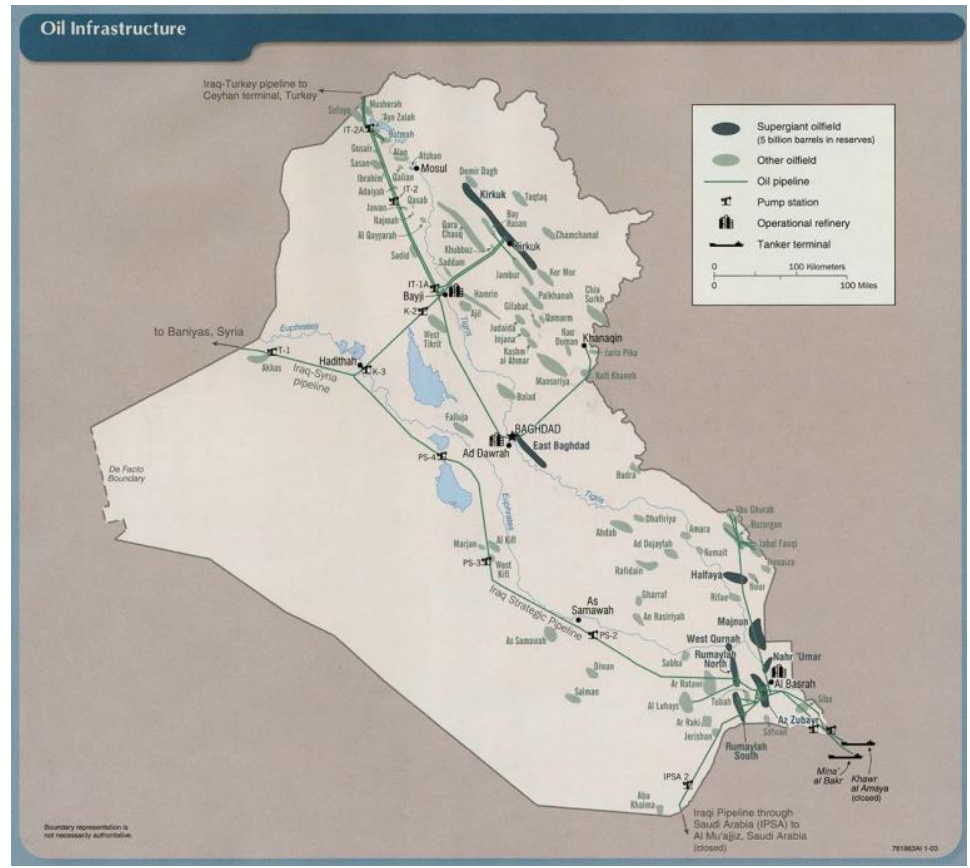

Map 5: Iraq's oil infrastructure. ${ }^{44}$

While the above legislation appears to provide for the citizens of the entire country, the location of the Kirkuk field (easily one of the two most productive in Iraq) within Kurdistan and the disputed territories has put the KRG at odds with the Central Government in Baghdad over management of the field. Major points of contention appear to stem from the leverage to be gained from controlling the field, the capacity to increase revenues independent of the Central Government, and potential secondary and tertiary benefits associated with outside investments. ${ }^{45}$

\section{Conclusions}

I submit that the Kurd-Arab fault line within Iraq is one of the most significant impediments to long-term stability within the country. While other problems such as insurgent group activity, sectarian violence, corruption, sponsored terrorism and an underdeveloped economic infrastructure will certainly impede progress toward peace and stability, none of the above compares to the worst-case 
scenario where conflict erupts between Iraq's Kurds and Arabs. In this hypothetical instance, both sides would be armed and equipped with a trained military force and are territorially based on both sides of a shared, yet contested region that holds tremendous economic potential, as well as conflicting residential claims. Moreover, an open conflict between Iraq's Kurds and Arabs would undoubtedly have regional, if not global, implications, with both sides potentially garnering support from throughout the Middle East and perhaps beyond. While Kurds account for 15-20\% of Iraq's citizens, the Kurdish population is estimated to be around 30 million when one includes the bordering countries of Iran, Turkey and Syria, ${ }^{46}$ so any Iraqi solution to its Kurd-Arab tensions must be considered within a regional context and with regard for the potential impacts on neighbouring countries.

The Kurd's longing for a homeland has endured for many years and one cannot expect that aspiration to subside, as it has been passed on from one generation to the next, becoming an integral aspect of the Kurdish national identity. The current arrangement as a federal autonomous region comes close to reality and provides added benefits of being part of a new and democratic Iraq. However, while the GOI's long-held notion is restricted to the three governorates of Dohuk, Erbil and Sulaymaniyah, the KRG has extended claims to the entire governorate of Kirkuk and parts of four other provinces: Ninewa, Salah al-Din, Diyala and Waset, whose boundaries were manipulated during the former regime. ${ }^{47}$ Consequently, defining the autonomous region with precise boundaries remains an elusive task.

The status of Kirkuk can also be expected to remain contentious. Although the Iraqi Constitution mandates the reversal of the Arabisation policy in Kirkuk, there is no practical means to achieve this policy goal. While Article 140 calls for ,normalising' Kirkuk, various interpretations and ethnic rivalries have precluded meaningful progress. Not only is the city important symbolically, but it is the country's third largest metropolitan area and it is situated atop an oil field that holds as much as $13 \%$ of Iraq's proven reserves. ${ }^{48}$ Previous gerrymandering by Saddam Hussein to redraw the provincial boundaries, and recurring expulsions of both Kurdish and Arab residents during continuous conflicts or Arabisation and reverseArabisation campaigns have made Kirkuk the most contested space in Iraq.

Iraq's oil impasse between the KRG and GOI stems largely from the Kirkuk oil field being located within the disputed territories. While all of Iraq seems to benefit from the current revenue-sharing policy, the arrangement is neither effective nor efficient, and certainly not free of corruption. Moreover, from the KRG perspective, it renders the autonomous region totally dependent upon the central government for revenue, as well as future investment and development. 
Iraq's Kurdish-Arab fault line stems from multiple, but interrelated issues. Collectively, these issues are a significant hindrance to continued progress and unification within the country, as well as regional peace and stability. Despite the recent national elections and the projected withdrawal of US forces, Iraq is in a precarious position as a young and fragile democracy with an uncertain future.

\section{Endnotes}

${ }^{1}$ Ghareeb, E. "The Kurdish issue". In Inati, SC (ed), Iraq: Its history, people, and politics, Amherst, NY: Humanity Books, 2003.

${ }^{2}$ Limbert, J. "The origins and appearance of the Kurds in pre-Islamic Iran". Iranian Studies 1/2. 1968. 41-51.

${ }^{3}$ Ghareeb, op. cit.

${ }^{4}$ Ibid:; Limbert, op. cit.

${ }^{5}$ Stewart, DJ. The Middle East today: Political, geographical, and cultural perspectives. London: Routledge, 2009.

${ }^{6}$ United Nations Environment Programme (UNEP). Desk study on the environment in Iraq. Geneva, 2003.

${ }^{7}$ Karsh, E. The Iran-Iraq War: 1980-1988. Oxford: Osprey, 2002.

${ }^{8}$ Tripp, C. A history of Iraq. $3^{\text {rd }}$ ed. Cambridge: Cambridge University Press, 2007.

${ }^{9}$ Abdullah, R. Ayaam Anfaal. Cairo: Nashr Jaami'at Al-Qaahira, 1998; Lawrence, Q. Invisible nation. New York: Walker, 2008.

${ }^{10}$ Central Intelligence Agency (CIA), 1992.

${ }^{11}$ International Crisis Group (ICG). Oil for soil: Toward a grand bargain on Iraq and the Kurds. Middle East Report No. 80. 28 October 2008.

${ }^{12}$ Middle East Institute. How to solve the Kirkuk question. Summary report, 2008; ICG, op. cit.

${ }^{13}$ Khadduri, M \& Ghareeb, E. War in the Gulf, 1990-1: The Iraqi-Kurdish conflict and its implications. New York: Oxford University Press, 1997.

${ }^{14}$ Tripp, op. cit.

${ }^{15}$ McDowell, D. A modern history of the Kurds. New York: IB Taurus, 1996.

${ }^{16}$ Tripp, op. cit.

${ }^{17}$ Stansfield, GRV. "The Kurdish dilemma: The golden era threatened". In Dodge, T \& Simon, S (eds), Iraq at the crossroads: State and society in the shadow regime change, New York: Oxford University Press, 2003.

${ }^{18}$ Ghareeb, op. cit.

${ }^{19}$ Maya, M. "The politics of rift: Politics across parties in the Iraqi north". AlMustashrik. October 2001. 
${ }^{20}$ Available at http://www.af.mil/art/mediagallery.asp?galleryID=193\&?id=$1 \&$ page $=1 \&$ count $=24$. Accessed on 27 May 2011 .

${ }^{21}$ Tripp, op. cit.

${ }^{22}$ Cagaptay, S. "360 degrees from Irbil: The KRG's views of its neighborhood". In Cagaptay, S (ed), The future of the Iraqi Kurds, Policy Focus \#85.

Washington, D.C: The Washington Institute for Near East Policy, 2008, 12 20.

${ }^{23}$ Wright, D. "Kurds reclaim Kirkuk and dreams after Saddam: Kurds take back their city, culture, and stake in Iraqi oil industry". ABC News, Nightline. May 72003.

${ }^{24}$ Cagaptay, op. cit.

${ }^{25}$ Bowen, WH. Undoing Saddam: From occupation to sovereignty in northern Iraq. Washington, DC: Potomic Books, 2007; Lake, E. "Kurds anxious over US withdrawal". Washington Times. 17 April 2009. 13.

${ }^{26}$ Bowen, op. cit.; Hoffman, M. "Readying for new order: US soldiers prepare Iraqis, Kurds for a future together without them". Army Times. 28 February 2011. 18; Lawrence, op. cit.

${ }^{27}$ Hoffman, op. cit.

${ }^{28}$ Bowen, op. cit.

${ }^{29}$ U.S. Army product, Multi-National Division North, 2009 (unpublished map).

${ }^{30}$ Ibid.

${ }^{31}$ Hoffman, op. cit.

${ }^{32}$ Bowen, op. cit.; Stewart, op. cit.

${ }^{33}$ Stewart, op. cit.

${ }^{34}$ Knights, M. "Guiding the Kurdish role in securing northern Iraq". In Cagaptay, S (ed), The future of the Iraqi Kurds, Policy Focus \#85. Washington, D.C: The Washington Institute for Near East Policy, 2008, 21-30.

${ }^{35}$ Ibid.

${ }^{36}$ White, W. Iraq: Security gains in jeopardy. Commentary. Washington, D.C: Middle East Institute, 19 September 2008.

${ }^{37}$ U.S. Army product, Multi-National Division North, 2009 (unpublished map).

${ }^{38}$ Romano, D. Kirkuk: Constitutional promises unfulfilled. The Middle East Institute, Viewpoints: Iraq's refugee and IDP crisis, 2008, 36-39. $<$ http://www.mei.edu/Publications/WebPublications/Viewpoints.aspx $>$ Accessed on 27 May 2011.

${ }^{39}$ Rubin, M. "Are the Kurds Pariah minority?" Social Research Journal. Spring. 2003. 6 . 
${ }^{40}$ Londono, E. "Kurds, Arabs maneuver ahead of UN. Report on N. Iraq". Washington Post. 17 April 2009. 10.

${ }^{41}$ Ibid.

${ }^{42}$ Kumins, L. Iraq oil: Reserves, production, and potential reserves. CRS Report for Congress, Order Code RS21626. 24 April 2006.

${ }^{43}$ Flake, A. 2008. "The oil impasse". In Cagaptay, S (ed), The future of the Iraqi Kurds, Policy Focus \#85. Washington, D.C: The Washington Institute for Near East Policy, 2008, 31-35.

${ }^{44}$ Central Intelligence Agency (CIA), 2003

${ }^{45}$ Ibid.

${ }^{46}$ Stewart, op. cit.

${ }^{47}$ ICG, op. cit.

${ }^{48}$ Ibid. 